UDC 620.178

\title{
DETERMINATION OF STRESSES IN MATERIALS WITH EVAPORATED COATINGS
}

\author{
Oleksandr Hasiy; Ihor Horbachevsky
}

\author{
Ukrainian National Forestry University, Lviv, Ukraine
}

\begin{abstract}
Summary. The paper considers the structure of the stress state in thin ion-plasma coatings and the influence of various factors on the efficiency of structures of this type of coatings. A comparative analysis of theoretical and experimental methods for determination of the main mechanical characteristics of the coatings is carried out, a model of the problem for analytical determination of the stressed state is proposed. A comparison of the results obtained with known models in the framework of the model is made.

Key words: ion-plasma coating, residual stresses, thermal stresses, internal stresses, Young's modulus, Poisson coefficient, adhesion work, strength limit.
\end{abstract}

https://doi.org/10.33108/visnyk_tntu2018.04.024

Received 14.01.2019

Statement of the problem. The growth of reliability and durability of machine parts and mechanisms, technological equipment and cutting tools is the challenging problem in various branches of industry. This is due to the fact that the costs of repairs and manufacturing of spare parts cause significant material and social damages. Among all the existing approaches concerning this problem solving, a number of methods of structural materials surface strengthening providing significant improvement of metals and alloys properties play an important role. The main place among these methods is occupied by electrophysical methods of coating, which are the most high-tech and environmentally friendly ones. The most progressive is the method of condensates depositing in vacuum under the conditions of the base ion bombardment (CIB method). This kind of processes are used to obtain wear-resistant, heatresistant multilayer coatings. Such are, for example, TiN, TIC, $\mathrm{ZrN}$ and HfN. The coatings operational properties directly depend on the stressed state in them. Therefore, determination of the stressed state structure in coatings and factors that affect it is an important task.

Analysis of the available research results. Stresses occur in the process of ion bombardment due to the changes in the crystalline structure, as well as due to the differences in the thermal expansion of the coating and block, the applied load and microdefects in the coating itself. During operation, the applied external load affects the size and nature of the stresses in the coating. The stress gradients can result in the coating fracture or its separation from the base.

As it is proved by different scholars (particularly [1], [2]), the total stress in coating $\sigma$ is the sum of three components:

$$
\sigma^{(n)}=\sigma^{(3)}+\sigma^{(T)}+\sigma^{(8)}
$$

where $\sigma^{(3)}$ are stresses occurring in the process of coating, they are called residual; $\sigma^{(8)}$ are stresses from the applied forces; $\sigma^{(T)}$ is thermal component.

As mentioned in this paper [3], investigations carried out by E. Orovan [4], M. Davydenkov [5], I. Birger [6], L. Dehtyar [7], A. Vahramyan, Yu. Petrova and Z. Solovyova [8, 9], Ya. Savchuk [10] and other researchers are concerned with residual stresses in coatings. The structuring of all existing methods of residual stresses investigation, their 
advantages and disadvantages are described in paper [3]. In this paper we will focus in theoretical and theoretical-experimental methods. The Irish scientist George Johnston Stoney [11] laid their foundations in 1909. He derived the formula that connects the stresses in coating with the material bending radius after coating

$$
\sigma=\frac{E H^{2} \kappa}{6 h(1-v)}
$$

known as Stoney's formula. Here and $H$ and $h$ are relatively the base thickness and coating; $E$ and $v$ are Young's modulus and Poisson's coefficient of base material; $\kappa$ is the surface curvature is bent due to the coating (Fig. 1); $\kappa=\frac{1}{R}$.

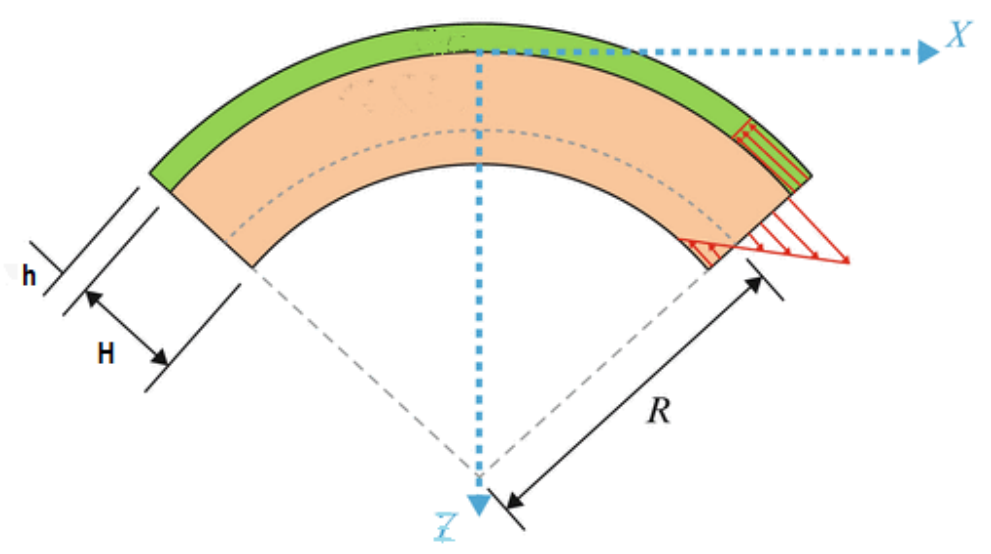

Figure 1. Scheme of the effect of the coating on the curvature of the surface

Later, a large number of papers where formula (2) was specified appeared among which papers by V.V. Lyubimov and others. [2] and X. Feng, Y. Huang, A. Rosakis [12, 13] should be noted. The authors of paper [3] offered their theoretical-experimental method for residual stresses determination. Its essence is to determine the stress $\sigma^{(3)}$ through the solution of the problem of the plane stressed state of the plate with a thin coating $\mathrm{h}<<\mathrm{H}$ (the thickness of the condensate film is $\mathrm{h}=1 \div 10 \mu \mathrm{m}$ and the thickness of the sample is $\mathrm{H}=0,5 \div 1 \mathrm{~mm}$ ) coating (Fig. 2).
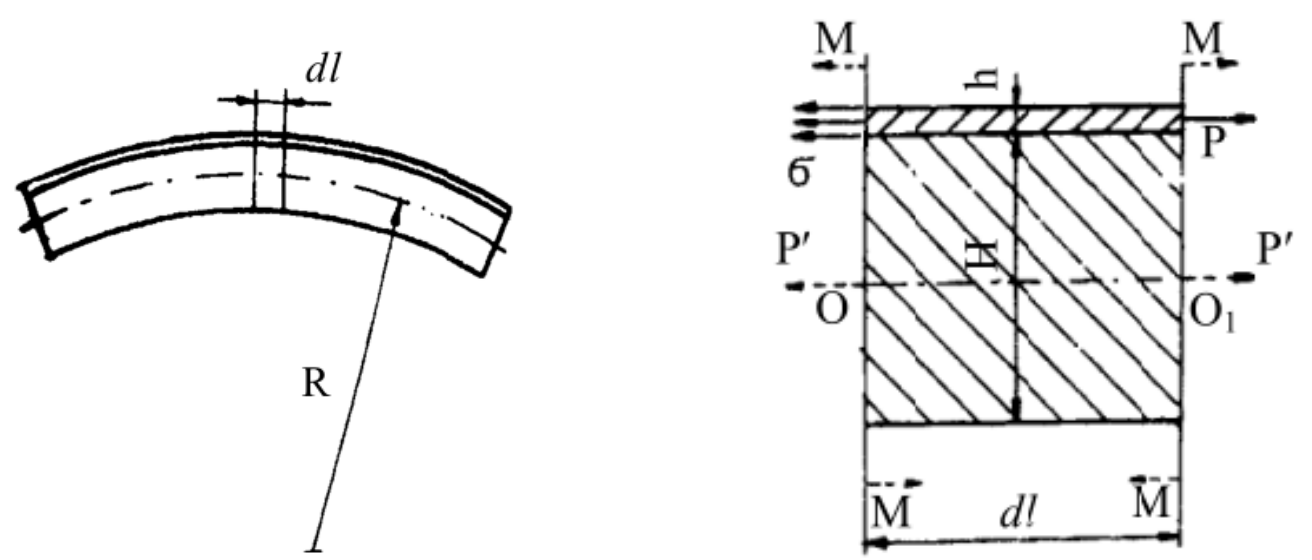

Figure 2. Calculation scheme for determining of stresses [3] 
Using the equilibrium equation of the bent bar with thin coating, the authors received for $\sigma^{(3)}$ expression

$$
\sigma^{(3)}=\frac{E H^{2}}{6 R h\left(1-v_{1}^{2}\right)},
$$

where $v_{1}$ is Poisson coefficient for the coating material. By formula (3) and the following experiments the stresses in the coating were determined. Vacuum ion-plasma coatings Ti, TiN, Ti-Ni-N, Ni and Mo-N sprayed at temperature $400^{\circ} \mathrm{C} \mathrm{C}$ and cooled to $20^{\circ} \mathrm{C}$ were investigated in paper [14]. The calculation of residual stresses $\sigma^{(3)}$ showed that in all investigated coatings the compressive stresses occurred. This fact can be considered positive when the body is exposed to further loading by external forces, particularly while working under friction conditions. The same results were confirmed by Ya.I. Savchuk [10] investigations. In his paper, the experimental values of residual stresses were determined according to the samples deformation by gradual layers removal. It is shown that in the titanium nitride coatings the compressive stress depends on the layer thickness and the larger thickness is, the smaller is the stress.

The objective of the paper is to carry out the comparative analysis of theoretical and experimental methods for determining the basic mechanical characteristics of the coatings and to offer the model of the problem of the stress state analytical determination, to modulate the stress state in the coating and, on this basis, to determine the critical value of the stresses under which the coating fractures or separates, to compare the results obtained with known ones within the model framework.

Statement of the problem. Significant thermal stresses in coatings occurs in two cases: a) under the large difference in the values of temperature coefficients of linear expansion (TCLE) of coating materials and the bases; b) under considerable difference in the temperature of the coating formation and its operation. The temperature stresses are also affected by the temperature gradient along the thickness during the coating formation. Assuming that the coating thickness is substantially less than the substrate thickness, and the deformations do not exceed the plastic boundary, the monograph [1] authors derived the formula for stresses $\sigma^{(T)}$

$$
\sigma^{(T)}=\frac{E_{1}}{1-v_{1}} \Delta a \Delta T,
$$

where $\Delta \alpha$ is the difference of TCLE coating and the basis; $\Delta T$ is temperature difference during spraying and measurement. The obvious drawback of formula (4) is the absence of coating thickness effect.

The theoretical-experimental method for stresses $\sigma^{(T)}$ determination taking into account the coating thickness is proposed in paper [14] according to the formula

$$
\sigma^{(T)}=\left(\frac{1}{R_{T}}-\frac{1}{R_{1}}\right) \cdot \frac{E_{T}}{6 h \cdot\left(1-v_{1 T}^{2}\right)},
$$

where $E_{T}$ is the modulus of the base material elasticity at measuring temperature $\left(\mathrm{t}_{\mathrm{i}}{ }^{\circ}\right) ; v_{1 T}$ is Poisson coefficient of the coating material at a measuring temperature $\left(\mathrm{t}_{\mathrm{i}}^{\circ}\right) ; R_{1}, R_{T}$ are the 
radii of the coated plate curvature: before and after coating. The radii were calculated during the heating process according to the curve of the sample arrow. The residual stress values for ion-plasma coatings Ti, TiN, Ti-Ni-N, Ni and Mo-N sprayed at temperature $400^{\circ} \mathrm{C}$ and cooled to $20^{\circ} \mathrm{C}$ were calculated by means of these experiments. It is concluded that during the spraying of vacuum ion-plasma coatings the compressive stresses occur in the obtained condensates. The value of these stresses is proportional to the difference between TCLE of the base and the coating, as well as the modulus of the condensate material elasticity. Stresses are formed due to structural and thermal factors. The values of such stresses depend on the temperature of the base during the spraying process. The disadvantage of this method is the failure to take into account the fact that the thermophysical characteristics of ion-plasma condensates change with temperature change.

It is shown in paper [15] that withing the range of ion spray temperatures (100 $800^{\circ} \mathrm{C}$ ) the dependence of TCLE on temperature $T$ can be assumed as linear. Therefore, for stresses $\sigma^{(T)}(z)$ in the coating at level $z$ above substrate at temperature $T=T(z)$, the following formula is offered by the author of paper [16]:

$$
\sigma^{(T)}(z)=H \int_{T_{0}}^{T(z)} \frac{A+B T(z)+D T^{2}(z)+K T^{3}(z)}{R+S T(z)} \cdot d T(z)
$$

where $T_{0}$ is the temperature at spray beginning; $A=a_{0} a_{1} c_{1} ; B=a_{0} b_{1} c_{1}+a_{1} b_{1} c_{1}+a_{0} a_{1} d_{1}$;

$D=a_{0} b_{1} d_{1}+a_{1} b_{0} d_{1}+b_{0} b_{1} c_{1} ; K=b_{0} b_{1} d_{1} ; R=\left(1-v_{1}\right) H a_{0}+\left(1-v_{0}\right) h a_{1} ;$

$S=\left(1-v_{1}\right) H b_{0}+\left(1-v_{0}\right) h b_{1}$, where $a_{0}, a_{1}, b_{0}, b_{1}, c_{1}$ i $d_{1}$ are the coefficients in the following equations; $E_{1}=a_{1}+b_{1} T(z) ; E_{0}=a_{0}+b_{0} T(z) ; \Delta \alpha_{1}=\alpha_{1}-\alpha_{0}=c_{1}+d_{1} T(z)$.

The change function $T(z)$ should be simulated for the investigated coating. Indices 1 and 0 are related to the coating and the bases.

Formulation of the coating. We offer to consider the body with the coating under the plain deformation conditions. The axes of coordinates are selected as shown in Fig. 3. Let us assume that the coating thickness $h$ is considerably smaller than the base thickness $h<<H$; the stresses $\sigma_{x}$ and $\sigma_{y}$ in the coating do not exceed the elastic limit. We consider the availability of deep scratches or areas with imperfect adhesion with $L$ length at the contact point (Fig. 4). Therefore, the stresses occurring in the coating can cause the fracture of both coating itself and its separation from the base [17].

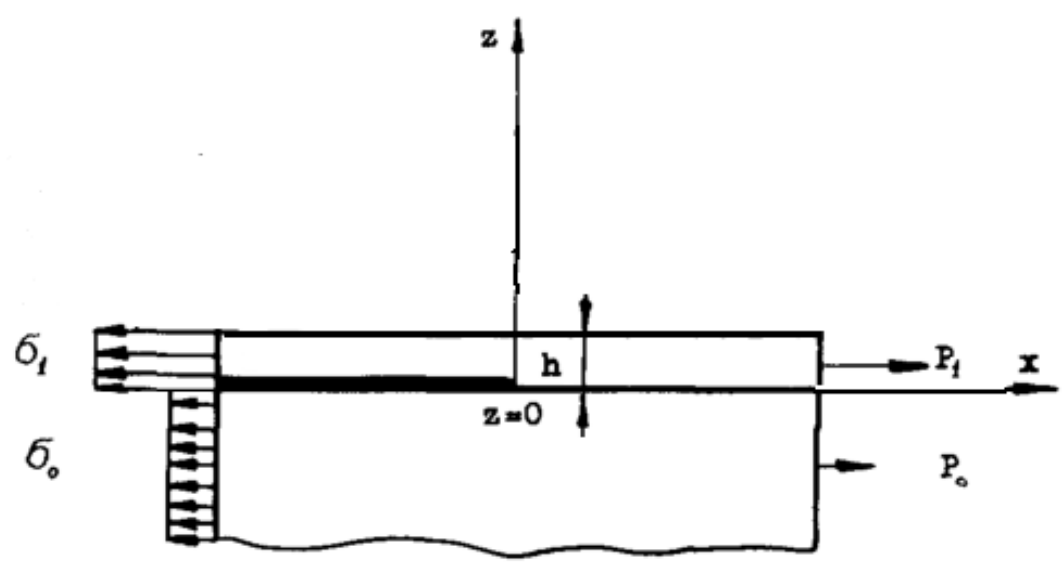

Figure 3. Coated body in plane deformation 
Separation will occur either through the coating fracture or by cracks extension along the interface surface, starting from scratch, or due to deformations over the area of imperfect adhesion caused by the applied compression forces [18] (Fig. 4). It is necessary to determine the critical values of external forces provoking the destruction of the coating.

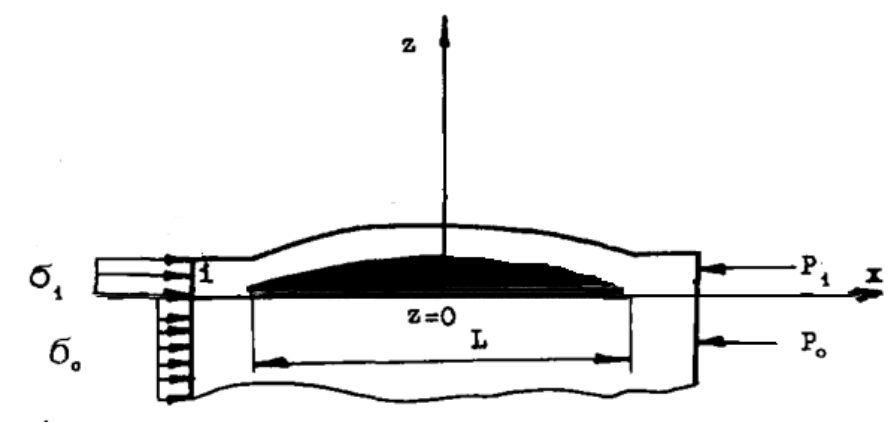

Figure 4. The substrate with a coating with an imperfect adhesion area under the influence of external forces

First, let us consider the case of coating fracture by crack extension along the contact area or coating cracking under the action of tensile forces. Fracture will not occur if tension in the coating does not exceed the coating boundary strength, i.e.

$$
\sigma_{1}^{(B)}(z)<\sigma_{1}^{(B)}
$$

where $\sigma_{1}^{(B)}$ is the coating material tensile strength. (Other fracture mechanisms are not considered). The strength is related to the stresses by dependence

$$
P_{1}=h \cdot \int_{0}^{h} \sigma_{1}^{(\theta)}(z) \cdot d z
$$

To find the critical value of stresses $\sigma_{1}^{(8)}$ taking into account that $h<<H$ let us simulate the problem by known one for the infinite half-space with the coating for $0<z \leq h$. On the media interface at $x<0$ two identical semi-infinite cracks where zero tangent stresses are formed. This problem is called modified Kelly problem, and its solution by J-integral method is derived by G.P. Cherepanov [19]. He defines the critical value of the deformation at which plate cracking or chipping occurs:

$$
\varepsilon_{1}=\sqrt{\frac{2 \gamma_{1}^{a} \cdot\left(1-v_{1}^{2}\right)}{h E_{1}}}
$$

where $\gamma_{1}^{a}$ is the adhesion work; $v_{1}, E_{1}$ are relatively Poisson coefficient and the Young modulus for coating. Taking into account that the stresses and deformations remain elastic, Hooke's law is justified:

$$
\sigma_{1}^{(в)}=\frac{\varepsilon_{1} E_{1}}{1-v_{1}^{2}} .
$$

If we substitute the result (9) into (10), we derive the formula for the determination of the stress critical value 


$$
\sigma_{1}^{(\theta)}=\sqrt{\frac{2 \gamma_{i}^{a} E_{1}}{h\left(1-v_{1}^{2}\right)}} .
$$

The adhesion work $\gamma_{i}^{a}$ adhesion can be determined experimentally, as shown, especially, in [20,21].

Results of the investigation and their discussion. In the framework of our coating model based on the formulas (1) and (11), taking into account the values of residual stresses [14] and the work of adhesion [2], the graphs for full stresses $\left(\sigma^{(n)}=\sigma_{1}^{(8)}+\sigma^{(3)}\right)$ in coatings made of Ti (Fig. 5), TiN (Fig. 6), Ti-Ni-N (Fig. 7) are constructed. Thermal stresses are not calculated in this case.

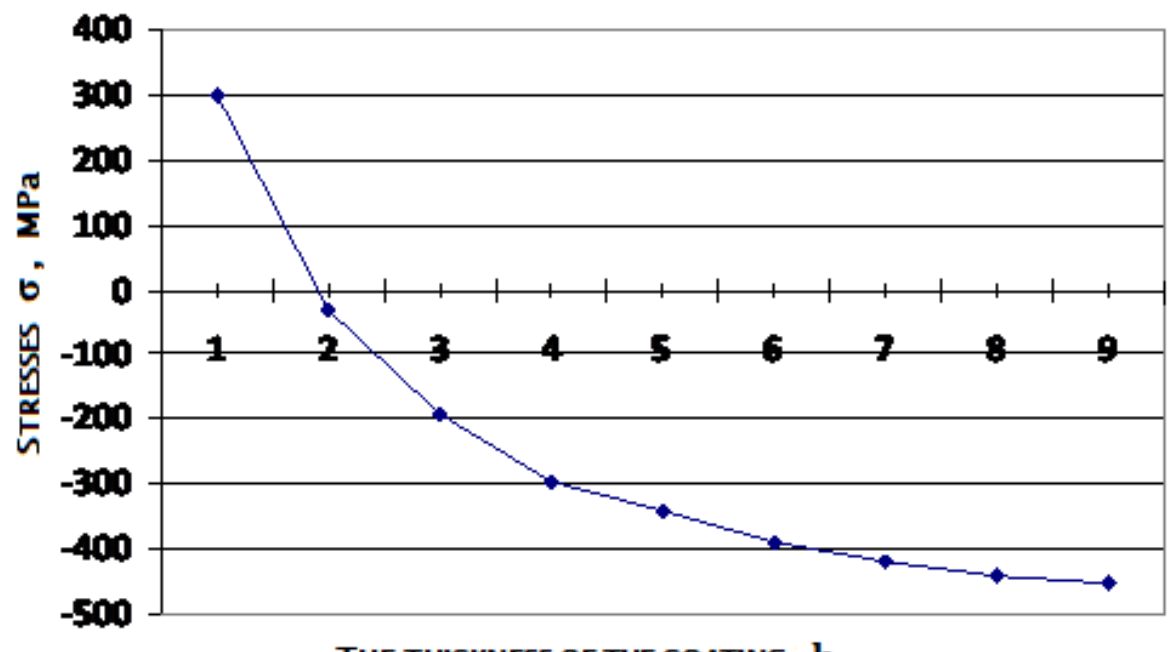

THE THICKNESS OF THE COATING $\mathbf{h}, \boldsymbol{\mu m}$

Figure 5. The stresses in the Ti coating under the action of tensile forces on depend of coating thickness:

$$
\gamma^{a}=45 \frac{J}{m^{2}} ; \sigma^{(3)}=4 \mathrm{GPa} \text { [22] }
$$

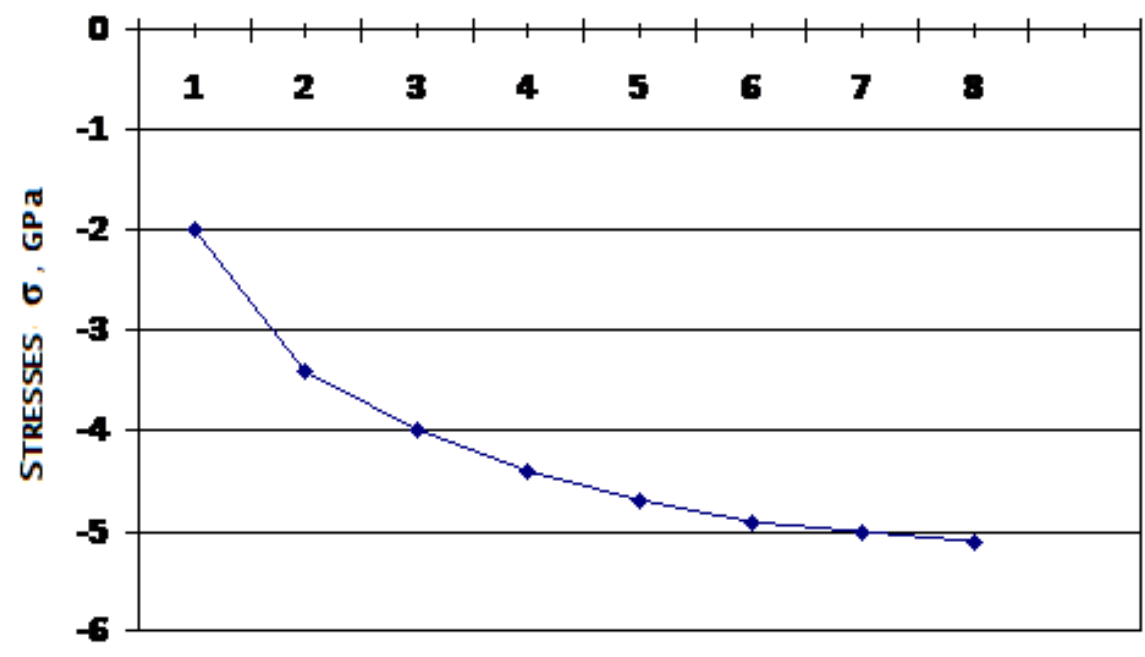

THE THICKNESS OF THE COATING $\mathbf{h}, \mu \mathrm{m}$

Figure 6. The stresses in the TiN coating under the action of tensile forces on depend of the coating thickness:

$$
\gamma^{a}=25 \frac{J}{m^{2}} ; \sigma^{(3)}=6820 \mathrm{MPa}
$$




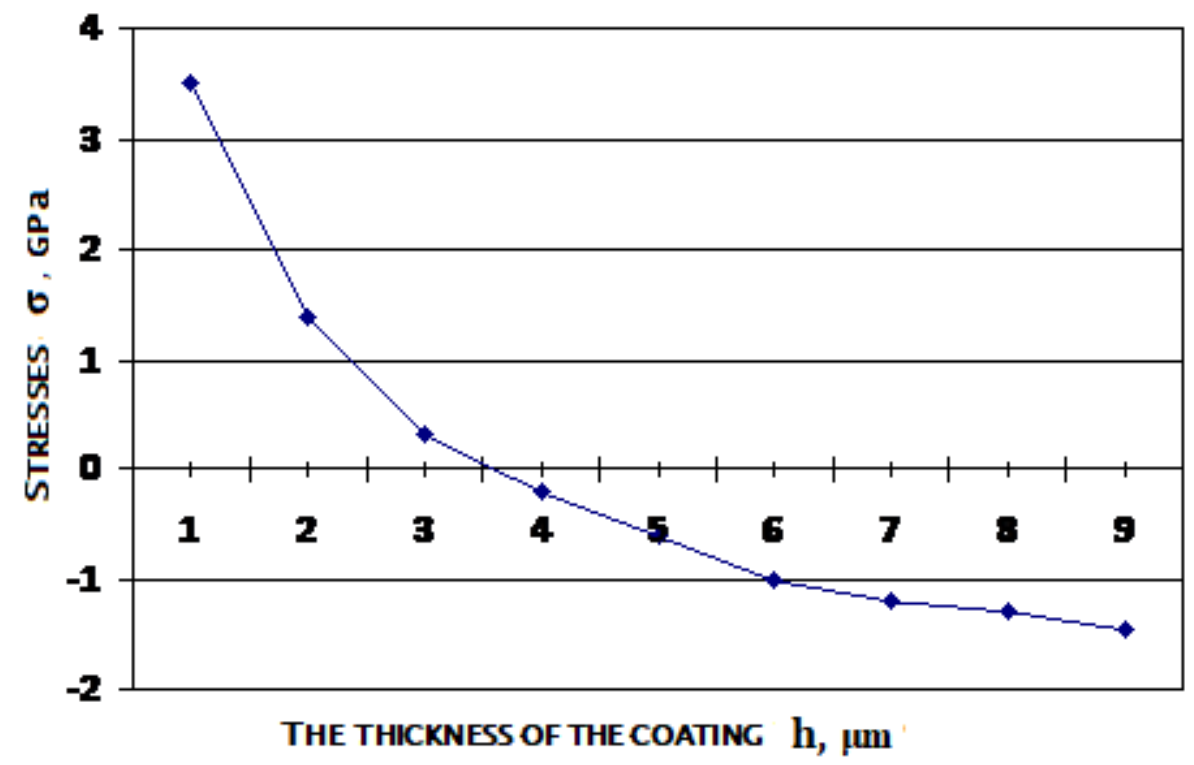

Figure 7. The stresses in the Ti-Ni-N coating under the action of tensile forces on depend of the coating thickness: $\gamma^{a}=60 \frac{\mathrm{J}}{\mathrm{m}^{2}} ; \sigma^{(3)}=840 \mathrm{MPa}$

As it is evident from the figures, the stresses in coatings decrease with increase of their thickness and are compressible due to high residual stresses. This is especially obvious in titanium coatings, which, in addition, at the temperature of ion bombardment lose their initial mechanical characteristics and become anisotropic. The use of TiN or Ti-Ni-N base coatings make it possible to increase their fatigue strength. It is possible to investigate the nature of stress state changes more competently in case of the sample deformation measurement directly during spraying.

Taking into account formula (8), it is possible to find the critical value of the external forces $P$, which will cause stratification or destruction of the coating.

Let us consider the substrate compression with the coating, if due to imperfect adhesion, the area with characteristic size $L$ appeared on the interface surface (Fig. 4). The author of the paper [19], and for this case, simulated the problem and found the critical value of the deformation in which the coating is expanded. This can lead to destruction. The value is equal to:

$$
\varepsilon_{1}=\frac{\pi^{2} h^{2}\left(1-v_{1}^{2}\right)}{3 L^{2}}
$$

The critical stress value conforms with it

$$
\sigma_{1}^{(6)}=\frac{\pi^{2} E_{1} h^{2}}{3 L^{2}}
$$

and compressive force

$$
P=\frac{\pi^{2} E_{1} h^{3}}{3 L^{2}}
$$


On the basis of equation (14) we obtain condition for preventing the coating fracture in the case of imperfect adhesion:

$$
P<\frac{\pi^{2} E_{1} h^{3}}{3 L^{2}}
$$

If efforts $P$ are known, one can assess the possibility of this coating type fracture.

Conclusions. The comparative analysis of theoretical and experimental methods for determining the main mechanical characteristics of coatings is carried out, specifically: due to the relationship between the stresses in coating with material bending radius after coating; due to the solution of the problem of the plane stressed state of the plate with thin coating using the equilibrium equation of the curved beam. The calculation of the residual stresses of Ti, TiN, Ti-N-N, Ni and Mo-N coatings carried out on its basis showed that in all investigated coatings the compressive stresses occur during spraying. It can be considered as positive during the following body loading by external forces, particularly while operating under friction conditions. The results of the investigations of the influence of the difference in temperature coefficient values of coating and basis linear expansion on the residual stresses are analyzed. The estimated model for determining the critical stress values at which occur the peeling of the coating is proposed. Conditions for the beginning of the destruction of a coating are formulated, if zone with an imperfect adhesion appeared in the contact area of the coating and the substrate.

\section{References}

1. Uglov A.A., Anishhenko L.M., Kuzneczov S.E. Adgezionnaya sposobnost` plenok. Moscow, Radio i sviyaz`. 1987. 104 p. [In Russian].

2. Lyubimov V.V., Voevodin A.A., Spassky S.E., Yerokhin A.L. Stress analysis and failure possibility assessment of multilayer physically vapour deposited coatings. Thin Solid Films, 1992, vol. 207, pp. 117 - 125. https://doi.org/10.1016/0040-6090(92)90111-N

3. Shchuyko Ya.V., Holubets' V.M., Hasiy O.B. Kombinovanyy metod vyznachennya napruzhenoho stanu vakuumnykh yonno-plazmovykh pokryttiv. Problemy trybolohiyi - Problems of Tribology, 2004, no 3, pp. $47-52$ [In Ukranian].

4. Orowan E. Classification and Nomenclature of Internal Stresses. Proceedings of Symposium of Internal Stresses in Metals and Alloys. London. The Institute of Metals, 1948, pp. $47-59$.

5. Davy`denkov N.N. Izbranny`e trudy` (v 2-x t.). Kiev, Naukova dumka. 1981. Vol. 2. Pp. $319-359$. [In Russian].

6. Birger I.A. Ostatochny`e napryazheniya. Moscow, Mashgiz. 1963. 232 p. [In Russian].

7. Dextyar` L.I. Opredelenie ostatochny`x napryazhenij $\mathrm{v}$ pokry`tiyax $\mathrm{i}$ bimetallax. Kishinev, Kartya moldovenyaske. 1968. 175 p. [In Russian].

8. Vagramyan A.T., Petrova Yu.S. Fiziko-mexanicheskie svojstva e`lektroliticheskix osadkov. Moscow, AN SSSR Publ. 1960. 206 p. [In Russian].

9. Vagramyan A.T., Solov`eva Z.A. Metody` issledovaniya e`lektroosazhdeniya metallov. Moscow, AN SSSR Publ. 1960. 448 p. [In Russian].

10. Savchuk Ja.I. Povyshenie stojkosti diskovyh pil pri obrabotke drevesnostruzhechnyh plit naneseniem pokrytija nitrida titana : avtoref. dis. ... kand. tehn. nauk: 05.06.02. L'vov, 1984, 24 p. [In Russian].

11. Stoney G.G. The Tension of Metallic Films Deposited by Electrolysis. Proceedings of Royal Society London. Ser.A, 1909, vol. 82, pp. 172 - 175. https://doi.org/10.1098/rspa.1909.0021

12. Huang Y., Rosakis A.J. Extension of Stoney's Formula to Arbitrary Temperature Distributions in Thin Film/Substrate Systems. Journal of Applied Mechanics, 2007, vol. 74, pp. 1225 - 1233. https://doi.org/ $10.1115 / 1.2744035$

13. Feng X., Huang Y., Rosakis A.J. Stresses in a Multilayer Thin Film/Substrate System Subjected to Nonuniform Temperature. Journal of Applied Mechanics, 2008, vol. 75, pp. 021022-1 - 021022-7. https://doi.org/10.1115/1.2755178

14. Holubets' V.M., Hasiy O.B., Shchuyko Ya.V. Rol' strukturnoho i temperaturnoho faktoriv u formuvanni napruzhenoho stanu vakuumnykh yonno-plazmovykh pokryttiv. Problemy trybolohiyi - Problems of Tribology, 2008, no 1, pp. $24-28$. [In Ukranian]. 
15. Francevich I.N. Uprugie postoyanny’e i moduli uprugosti metallov i nemetallov. Kiev, Naukova dumka. 1982. 260 p. [In Russian].

16. Zhuravlev G.I. Ximiya i texnologiya termostojkix neorganicheskix pokry`tij. Leningrad, Ximiya. Leningrad brunch. 1975. 199 p. [In Russian].

17. Arai T., Fujita H., Watanabe M. Evaluation of Adhesion Strength of Thin Hard Coatings, 1987, vol. 154, pp. 387 - 401. https://doi.org/10.1016/0040-6090(87)90381-6

18. Thouless M.D. Some Mechanics for the Adhesion of Thin Films. Thin Solid Films, 1989, vol. 181, pp. 397 - 406. https://doi.org/10.1016/0040-6090(89)90508-7

19. Cherepanov G.P. Mexanika razrusheniya kompozicionny`x materialov. Moscow, Nauka. 1983. 296 p. [In Russian].

20. Varchenya S.A., Simanovskis A., Stolyarova S.V. Adhesion of Thin Metallic Films to Non-metallic Substrates. Thin Solid Films, 1988, vol. 164, pp. 147 - 152. https://doi.org/10.1016/0040-6090(88)90125-3

21. Bull SJ., Rickerby D.S., Matthews A., Leyland A., Pace A.R., Valli J. The Use of Scratch Adhesion Testing for the Determination of Interfacial Adhesion - the Importance of Frictional Drag. Surface and Coatings Technology, 1988, vol. 36, pp. 503 - 517. https://doi.org/10.1016/0257-8972(88)90178-8

22. Andreev A.A., Sablev L.P., Grigor`ev S.N. Vakuumno-dugovy`e pokry`tiya. Xar`kov. NNC XFTI. 2010. 318 p. [In Russian].

\section{Список використаної літератури}

1. Углов, А.А. Адгезионная способность пленок [Текст] / А.А. Углов, Л.М. Анищенко, С.Е. Кузнецов. - М.: Радио и связь, 1987. - 104 с.

2. Lyubimov, V.V. Stress analysis and failure possibility assessment of multilayer physically vapour deposited coatings [Text] / V.V. Lyubimov, A.A. Voevodin, S.E. Spassky, A.L. Yerokhin // Thin Solid Films. 1992. Vol. 207. Рp. $117-125$.

3. Щуйко, Я.В. Комбінований метод визначення напруженого стану вакуумних йонно-плазмових покриттів [Текст] / Я.В. Щуйко, В.М. Голубець, О.Б. Гасій // Проблеми трибології. - 2004. № 3. - C. $47-52$.

4. Orowan, E. Classification and Nomenclature of Internal Stresses / E. Orowan // Proceedings of Symposium of Internal Stresses in Metals and Alloys. London. The Institute of Metals. - 1948. P. $47-59$.

5. Давыдснков, Н.Н. Избранные труды (в 2-х т.) [Текст] / Н.Н. Давыдснков. - К: Наук. думка, 1981. - Т. 2. - С. $319-359$

6. Биргер, И.А. Остаточные напряжения [Текст] / И.А. Биргер. - М.: Машгиз, 1963. - 232 с.

7. Дехтярь, Л.И. Определение остаточных напряжений в покрытиях и биметаллах [Текст]/ Л.И. Дехтярь. - Кишинев: Картя молдовеняске, 1968. - 175 с.

8. Ваграмян, А.Т. Физико-механические свойства электролитических осадков [Текст]/ А.Т. Ваграмян, Ю.С. Петрова. - М.: Изд-во АН СССР, 1960. - 206 с.

9. Ваграмян, А.Т. Методы исследования электроосаждения металлов. [Текст] / А.Г. Ваграмян, 3.А. Соловьева. - М.: Изд-во АН СССР, 1960. - 448 с.

10. Савчук, Я.И. Повышение стойкости дисковых пил при обработке древесностружечных плит нанесением покрытия нитрида титана: автореф. дис. ... канд. техн. наук: 05.06 .02 [Текст] / Я.И. Савчук. - Львов, 1984. - 24 с.

11. Stoney, G.G. The Tension of Metallic Films Deposited by Electrolysis [Text] / G.G. Stoney // Proceedings of Royal Society London. Ser.A. - 1909. - Vol. 82. - Р. 172 - 175. Режим доступа: https://doi.org/10.1098/rspa.1909.0021

12. Huang, Y. Extension of Stoney's Formula to Arbitrary Temperature Distributions in Thin Film/Substrate Systems [Text] / Y. Huang, A.J. Rosakis // Journal of Applied Mechanics. - 2007. - Vol. 74. P. 1225 - 1233. https://doi.org/ 10.1115/1.2744035

13. Feng, X. Stresses in a Multilayer Thin Film/Substrate System Subjected to Nonuniform Temperature [Text] / X. Feng, Y. Huang, A.J. Rosakis // Journal of Applied Mechanics. - 2008. - Vol. 75. P. 021022-1 - 021022-7. https://doi.org/10.1115/1.2755178

14. Голубець, В.М. Роль структурного і температурного факторів у формуванні напруженого стану вакуумних йонно-плазмових покриттів [Текст] / В.М. Голубець, О.Б. Гасій, Я.В. Щуйко // Проблеми трибології. - 2008. - № 1. - С. $24-28$.

15. Францевич, И.Н. Упругие постоянные и модули упругости металлов и неметаллов [Текст] / И.Н. Францевич. - К.: Наук. думка, 1982. - 260 с.

16. Журавлев, Г.И. Химия и технология термостойких неорганических покрытий [Текст] / Г.И. Журавлев. - Л.: Химия. Ленингр. отд-ние, 1975. - 199 с. 
17. Arai, T. Evaluation of Adhesion Strength of Thin Hard Coatings [Text] / T. Arai, H. Fujita, M. Watanabe // Thin Solid Films. - 1987. - Vol. 154. - P. 387 - 401. https://doi.org/10.1016/0040-6090(87)90381-6

18. Thouless, M.D. Some Mechanics for the Adhesion of Thin Films [Text] / M.D. Thouless // Thin Solid Films. - 1989. - Vol. 181. - P. 397 - 406. https://doi.org/10.1016/0040-6090(89)90508-7

19. Черепанов, Г.П. Механика разрушения композиционных материалов [Текст] / Г.П. Черепанов. М.: Наука, 1983. - 296 c.

20. Varchenya, S.A. Adhesion of Thin Metallic Films to Non-metallic Substrates [Text] / S.A. Varchenya, A. Simanovskis, S.V. Stolyarova // Thin Solid Films. - 1988. - Vol. 164. - P. 147 - 152. https://doi.org/ 10.1016/0040-6090(88)90125-3

21. Bull, SJ. The Use of Scratch Adhesion Testing for the Determination of Interfacial Adhesion - the Importance of Frictional Drag [Text] / S.J. Bull, D.S. Rickerby, A. Matthews, A. Leyland, A.R. Pace, J. Valli // Surface and Coatings Technology. - 1988. - Vol. 36. - P. 503 - 517. https://doi.org/10.1016/ 0257-8972(88) 90178-8

22. Андреев, А.А. Вакуумно-дуговые покрытия [Текст] / А.А. Андреев, Л.П. Саблев, С.Н. Григорьев. Харьков: ННЦ ХФТИ, 2010. - 318 с.

\title{
УДК 620.178
}

\section{ВИЗНАЧЕННЯ НАПРУЖЕНЬ У МАТЕРІАЛАХ 3 НАПИЛЕНИМИ ПОКРИТТЯМИ}

\section{Олександр Гасій; Ігор Горбачевський}

\author{
Національний лісотехнічний університет Украӥни, Львів, Украӥна
}

Резюме. Розглянуто структуру напруженого стану в тонких йонно-плазмових покриттях та вплив різних чинників на працездатність конструкиій з такого типу покриттями. Проведено порівняльний аналіз теоретико-експериментальних методів визначення основних механічних характеристик покриттів, а саме: через співвідношення, щзо пов'язує напруження у покритті з радіусом вигину матеріалу після нанесення покриття; через розв'язок задачі про плоский напружений стан пластини з нанесеним тонким покриттям з використанням рівняння рівноваги зігнутої балки. Розрахунок залишкових напружень покриттів Ti, TiN, Ti-Ni-N, Ni i Mo-N показав, щьо у всіх досліджуваних покриттях при напиленні виникають стискуючі напруження, щчо можна вважати позитивом при подальшому навантаженні тіла зовнішніми зусиллями, зокрема під час роботи в умовах тертя. Проаналізовано результати досліджень впливу різниці у значеннях температурного коефіцієнта лінійного розширення покриття та основи на залишкові напруження. Запропоновано модель для визначення критичного значення напружень, за якого відбудеться відшаровування покриття за умови, щзо товщина покриття суттево менша товщини основи, а напруження у покритті не перевищують границю пружності. Відтак відшаровування відбуватиметься або через руйнування покриття, або шляхом поширення тріщини вздовж гранииі контакту, починаючи від подряпини, чи з причини деформацій над областю недосконалої адгезії, зумовлених прикладеними стискаючими зусиллями. Сформульовано умову уникнення руйнування покриття, якщо на поверхні розділу покриття та основи виникла ділянка з недосконалою адгезією. Побудовано графіки зміни напруження по товщині покриттів Ti, TiN, Ti-Ni-N.

Ключові слова: йонно-плазмове покриття, залишкові напруження, термічні напруження, внутрішні напруження, модуль Юнга, коефіцієнт Пуассона, робота адгезї̈, границя міциності. 